\title{
ANALYSIS OF THE LOCAL PATTERN FOR THE PARANÁ SECTOR OF FOREST BASED PRODUCTS: 2005-2015
}

\author{
Keila Correa Bittencourt ${ }^{1}$, João Carlos Garzel Leodoro da Silva ${ }^{2}$, Romano Timofeiczyk Junior ${ }^{3}$, Junior Ruiz \\ Garcia $^{4}$, Vítor Afonso Hoeflich ${ }^{5}$

\begin{abstract}
${ }^{1}$ Federal University of Paraná, Ph.D. in Forestry Engineering, Curitiba, Paraná, Brazil - keila_cbittencourt@yahoo.com.br ${ }^{2}$ Federal University of Paraná, Rural Economy, and Extension Department, Curitiba, Paraná, Brazil - garzelufpr@gmail.com

${ }^{3}$ Federal University of Paraná, Rural Economy and Extension Department, Curitiba, Paraná, Brazil - romano.timo@ gmail.com ${ }^{4}$ Federal University of Paraná, Economy Department, Curitiba, Paraná, Brazil - jrgarcia1989@ gmail.com
\end{abstract} \\ ${ }^{5}$ Federal University of Paraná, Rural Economy, and Extension Department, Curitiba, Paraná, Brazil - vitor.ufpr@gmail.com
}

\begin{abstract}
Resumo
Análise do Padrão Locacional para o setor paranaense de produtos de base florestal: 2005-2015. O objetivo deste artigo foi analisar o Quociente Locacional (QL) para os principais produtos de base florestal por mesorregião paranaense entre 2005 e 2015, tais como sementes, mudas, lenha, serraria e laminador, celulose e papel e demais produtos (nó de pinho, álamo, mourão, lascas e resíduos florestais). O uso de indicadores e métodos para a identificação da concentração desses recursos e seus condicionantes podem subsidiar a concepção de políticas mais adequadas para a gestão dos recursos disponíveis, bem como orientar as necessidades de investimentos. Além disso, observou-se a escassez de trabalhos utilizando tal método (QL) na área florestal. $\mathrm{O}$ período foi selecionado de acordo com a disponibilidade de informações da Secretaria da Agricultura e Abastecimento (SEAB). Os resultados indicaram oscilações tanto positivas quanto negativas no período analisado. Essa dinâmica está relacionada as questões sazonais, burocráticas e de mercado. As conclusões levaram em consideração a cadeia produtiva da madeira para interpretar os resultados e não somente as especificidades de cada produto, dada a falta de informações disponíveis.

Palavras-chave: Produtos Florestais; Quociente Locacional; Estado do Paraná.
\end{abstract}

\begin{abstract}
The objective of this paper was to analyze the Locational Quotient (LQ) for the main products forest - by the Paraná mesoregion between 2005 and 2015, such as seeds, seedlings, firewood, sawmill and laminator, cellulose, and paper, and other (pine knot, poplar, fence posts, splinters, and forest waste). The use of indicators and methods to identify the concentration of these resources and their constraints can support the design of policies more suitable for the management of available resources, as well as guide the need for investments. Also, we observed the scarcity of research using such a method (LQ) in the forest area. The period was selected according to the availability of information from the Secretariat of Agriculture and Supply (SEAB). The results indicated both positive and negative oscillations in the analyzed period. This dynamic is related to seasonal, bureaucratic, and market issues. The conclusions considered the wood production chain to interpret the results and not only the specificities of each product, given the lack of available information.
\end{abstract}

Keywords: Forest Products; Location Quotient; state of Parana

\section{INTRODUCTION}

The well-being of society and the dynamics of the economy - generation of jobs and income - depend on natural resources, such as wood, water, oil, among others. The development of society for centuries was based on the direct extraction of natural resources, such as the extraction of wood from native forests. However, the reduction of native forest cover and its negative impacts on human well-being contributed to the development of forestry and a range of activities. Due to the use of forest products, the forest-based sector gained prominence in the economy for its ability to generate jobs and income, but also for contributing to environmental quality, such as maintaining fauna, flora, soil, carbon absorption, and storage, in addition to climate change (MOREIRA et al. 2017).

Brazil has become an important world producer in the forest-based sector because it has favorable edaphoclimatic and technological resources for forest production (MOREIRA et al. 2017). The sector is characterized by its diversity of products and by-products, such as the transformation of raw wood into cellulose, paper, wood panels, laminated floors, sawn wood, charcoal, and furniture, in addition to non-wood products. Thus, the forestry sector has shown positive prospects for expansion due to the intrinsic need of society by forest

FLORESTA, Curitiba, PR, v. 51, n. 2, p. 400-409, abril/jun 2021.

Bittencourt, K. C. et.al.

ISSN eletrônico 1982-4688 
producers (CENED, 2021).

The gross value of Brazilian production (GVP) reached R $\$ 19.1$ billion in 2017 (IBGE, 2019), distributed in: $\mathrm{R} \$ 4.3$ billion wood and non-wood extraction, $\mathrm{R} \$ 14.8$ billion in forestry. The sector generated more than 592,000 jobs in 2016, concentrated in the furniture sector $(176,000)$, cellulose, and paper $(171,000)$ (SNIF, 2019). In the state of Paraná accounted for 19.5\% of GVP in 2017, reaching R $\$ 3.7$ billion, concentrated in forestry with R\$ 3.3 billion, considering information from the Brazilian Institute of Geography and Statistics (IBGE, 2019). Thus, the state of Paraná is an important forest producer for the Brazilian economy. Data from the Secretariat of Agriculture and Supply (2019) reveal that the main products linked to the forestry sector were sawmill and rolling mill, firewood, cellulose and paper, yerba mate (non-wood), others.

Given the importance of the state of Parana in the Brazilian forestry sector, what is the space-time dynamics of Paraná's production? Is there any local pattern of production in the state of Paraná? In this context, the general objective of the work is to analyze the location pattern of the forest-based sector in the state of Paraná by product type between 2005 and 2015 . The analysis includes the sector of seeds, seedlings, firewood, sawmill and laminator, cellulose and paper, and other products (pine knot, poplar, fence posts, wood splinters, and forest residues).

The analysis was carried out based on the Locational Quotient (LQ) by mesoregion to reveal what is the regional specialization pattern of the forestry sector in the state of Paraná. LQ is an indicator widely used in the regional analysis (AZEVEDO JUNIOR et al. 2012; PIFFER et al. 2009; MATTEI, 2017).

It allows evaluating variations in the degree of regional specialization concerning production. The results of the regional specialization analysis of the forestry sector in the state of Paraná can provide information for the formulation of public policies, essential in the context of a sector intensive in natural resources and support infrastructures, such as roads and communication. In addition to contributing to the indication of subsidies for the formulation of public policies, the results can also contribute to the definition of private strategies regarding the development of the sector in Paraná.

The work is organized in four sections, in addition to the introduction. The second section presents the study area and methodological procedures. In the following, the results are presented. The fourth section discusses the results. In the last section, the final considerations are presented.

\section{MATERIALS AND METHODS}

\section{Study area}

The analysis was performed by mesoregion of Paraná as defined by the IBGE (2019) (Figure 1).

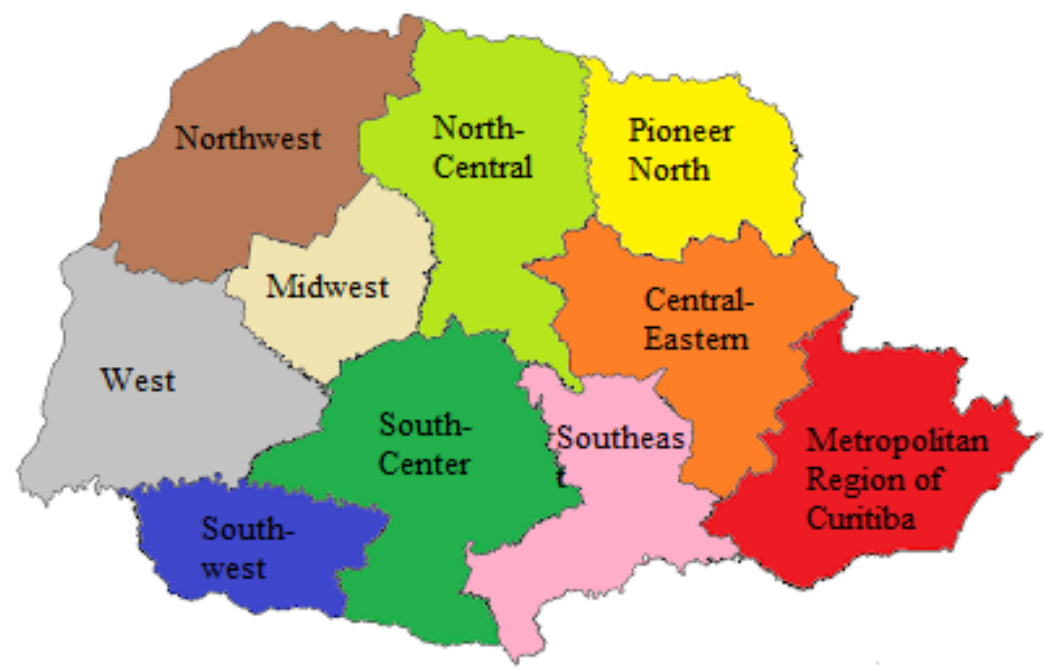

Figure 1. Mesoregions of the state of Paraná Figura1. Mesorregiões do estado do Paraná

Source: Based on Instituto de Brasileira de Geografia e Estatística (IBGE, 2021).

Fonte: Preparado com base em Instituto de Brasileira de Geografia e Estatística (IBGE, 2021). 
The state of Paraná has 199,000 km², 399 cities, an estimated population of 11.3 million people in 2018 , with a demographic density of 57 inhabitants $/ \mathrm{km}^{2}$ (IBGE, 2021). In 2016, the state of Paraná recorded a Gross Domestic Product at market prices (GDPmp) of R\$ 401.6 billion, placing it as the 5th largest Brazilian Gross Domestic Product (GDP); behind Rio Grande do Sul, Minas Gerais, Rio de Janeiro, and São Paulo (IBGE, 2021). The gross value added at market prices (GAVmp) of the state of Paraná reached R\$ 351 billion, distributed in (IBGE, 2021): services R\$177.2 billion, industry R\$90.3 billion and agriculture R\$ 34.7 billion.

\section{MATERIALS AND METHODS}

Economic development does not occur homogeneously in space but is manifested in growth hubs with different intensities (DELGADO et al. 2011). This process occurs due to spatial heterogeneity, whether due to natural aspects, such as the availability and quality of natural resources, or due to human aspects or those created by society, such as those defined by social and economic dynamics, infrastructure, production factors and institutions. In this sense, the analysis of the spatial or regional dynamics of economic activities can assist in the identification of locational and growth patterns. This type of analysis has been performed with the help of indicators or location measures, such as the Locational Quotient (LQ) (AZEVEDO JUNIOR et al. 2012; PIFFER et al. 2009; MATTEI et al. 2017; DELGADO et al. 2011).

Regional analysis indicators, therefore, can assist in the identification of spatial patterns regarding the organization of economic activities in relation to a reference space (AZEVEDO JUNIOR et al. 2012; PIFFER et al. 2009; MATTEI et al. 2017; DELGADO et al. 2011). It is worth mentioning that when regional indicators use the relative participation of each sector $(\mathrm{k})$ in relation to the reference space, the scale or size effect of the regions is canceled, reinforcing the reliability of the spatial analysis of economic activities (LIMA et al., 2006). However, the use of regional analysis indicators, such as the Locational Quotient, has been exploratory to investigate the heterogeneity in the occupation of the reference space.

In this study, the LQ was adapted to the available information, as well as the selection of the analyzed products. That is, when it comes to all products, it does not mean to say all the products grown and participating in the construction of the Gross Value of Production of that mesoregion, but it concerns all selected products: seeds, seedlings, firewood, sawmill and laminator, cellulose and paper and other products (pine knot, poplar, fence posts, wood splinters and forest residues). 2006b):

The Locational Quotient indicates the participation of a variable $i$ from region $j$ (Lima et al., 2006a;

$$
L Q_{i j}=\frac{\frac{E_{i j}}{\sum_{j} E_{i j}}}{\frac{\sum_{i} E_{i j}}{\sum_{i} \sum_{j} E_{i j}}}
$$

Where:

$E_{i j}$ : Production value of product $i$ from mesoregion $j$

$\sum_{j} E_{i j}$ : Production value of product $i$ from all mesoregions;

$\sum_{i} E_{i j}$ : Production value of all products analyzed in the mesoregion $j$;

$\sum_{i} \sum_{j} E_{i j}$ : Production value of all analyzed products and all mesoregions.

The calculation of the Locational Quotient considers a specific variable in relation to its total in each region. In this way, the same level (value) of specialization can be obtained by different factors, that is, the numerator refers to a specific analysis variable, for example, the value of each product in the forest-based sector, while the denominator considers a set of products, in this case, the total value of the products from the selected forest-based sector. In other words, the Locational Quotient has been used to compare the percentage of the production value of products from the forest-based sector of a mesoregion with the percentage share in the total of the state of Paraná. The Locational Quotient values are greater, less than or equal to 1. According to Marion Filho el al. (2015) the three ranges of LQ values can be interpreted as follows: 1) LQ $\geq$ (highly specialized); 2) $2 \leq \mathrm{LQ}$ $<4$ (specialized) and 3) $1 \leq \mathrm{LQ}<2$ (little specialized).

The Locational Quotient allows to evaluate the importance of a mesoregion in relation to the state, regarding the forest-based sector. The mesoregion with the highest production will not always have the highest production value, because the added value in each activity, region or process is different, which prevents the

FLORESTA, Curitiba, PR, v. 51, n. 2, p. 400-409, abril/jun 2021. 
universalization of a production value. Finally, the results of the Locational Quotient allow us to assess the sectors that would be interregional exporters (AZEVEDO JUNIOR et al. 2012; MATTEI et al. 2017; DELGADO et al. 2011).

\section{Database}

For the locational analysis of the forest-based sector in the mesoregions of Paraná, the Gross Value of Production (GVP) was used per selected product (seeds, seedlings, firewood, sawmill and laminator, cellulose and paper, and other products: pine knot, poplar, fence posts, splinters, and forest residues). The Department of Rural Economy (DERAL) of the State Secretariat estimates the GVP for Agriculture and Supply (SEAB).

Information from the Gross Value Added (GVA) database was used by the product selected from 2005 and 2015 and by the Paraná mesoregion provided by the State Department of Agriculture and Supply of the state of Paraná on its website (SEAB, 2021). The physical units of measurement for each product selected in this analysis are different, for example, while some products are in tons others are in cubic meters $\left(\mathrm{m}^{3}\right)$, a situation that prevents their aggregation, necessary for calculating the LQ. To circumvent this limitation, GVA is used, which is in monetary values.

\section{RESULTS}

The selected time interval (2005 and 2015) made it possible to obtain results on the level of participation of each product in the analyzed regions, inferring that forest products may be increasing or decreasing the level of productivity/commercialization, influenced by bureaucratic, institutional, logistics, soils, weather, climate, seasonal factors, occupation history, among other variables that can interfere both directly and indirectly in its cycle. analyzed:

The Table 1 shows the Locational Quotient for the production value of the six Forest Products in Paraná

Table 1. Locational Quotient (LQ) - Factor: Gross Value of Production (Paraná), 2005 and 2015.

Tabela 1. Quociente Locacional (QL) - Fator: Valor Bruto da Produção (Paraná), 2005 e 2015.

\begin{tabular}{|c|c|c|c|c|c|c|c|c|c|c|c|c|}
\hline \multirow{3}{*}{ Mesoregion } & \multicolumn{2}{|c|}{ Seeds } & \multicolumn{2}{|c|}{ Seedlings } & \multicolumn{2}{|c|}{ Firewood } & \multicolumn{2}{|c|}{$\begin{array}{l}\text { Sawmill and } \\
\text { Lamination }\end{array}$} & \multicolumn{2}{|c|}{$\begin{array}{l}\text { Cellulose and } \\
\text { paper }\end{array}$} & \multicolumn{2}{|c|}{$\begin{array}{l}\text { Other } \\
\text { Products }\end{array}$} \\
\hline & \multicolumn{2}{|c|}{ Year } & \multicolumn{2}{|c|}{ Year } & \multicolumn{2}{|c|}{ Year } & \multicolumn{2}{|c|}{ Year } & \multicolumn{2}{|c|}{ Year } & \multicolumn{2}{|c|}{ Year } \\
\hline & 2005 & 2015 & 2005 & 2015 & 2005 & 2015 & 2005 & 2015 & 2005 & 2015 & 2005 & 2015 \\
\hline Midwest & 0.00 & 0.00 & 2.66 & 1.90 & 2.25 & 2.59 & 1.07 & 0.84 & 0.06 & 0.00 & 0.38 & 0.06 \\
\hline Central-Eastern & 0.00 & 0.00 & 0.50 & 2.16 & 0.37 & 0.71 & 0.94 & 0.45 & 1.98 & 3.55 & 0.04 & 0.00 \\
\hline South-Center & 0.00 & 0.00 & 1.65 & 0.75 & 0.59 & 0.79 & 1.11 & 1.17 & 0.13 & 0.34 & 1.52 & 3.17 \\
\hline $\begin{array}{l}\text { Metropolitan } \\
\text { Region of } \\
\text { Curitiba }\end{array}$ & 0.00 & 0.00 & 0.24 & 0.60 & 0.71 & 0.41 & 1.09 & 1.28 & 0.77 & 0.61 & 0.06 & 0.00 \\
\hline Northwest & 0.00 & 0.00 & 5.52 & 4.30 & 4.60 & 4.83 & 0.92 & 0.22 & 0.00 & 0.00 & 0.90 & 0.00 \\
\hline Pioneer North & 0.00 & 0.00 & 0.63 & 0.29 & 2.86 & 1.45 & 0.69 & 1.14 & 1.01 & 0.13 & 6.96 & 0.00 \\
\hline North-Central & 0.00 & 0.00 & 2.79 & 1.64 & 2.18 & 1.25 & 0.99 & 1.15 & 0.34 & 0.15 & 1.70 & 0.38 \\
\hline West & 0.00 & 0.00 & 4.86 & 2.36 & 6.53 & 2.87 & 0.83 & 0.74 & 0.00 & 0.00 & 1.06 & 1.01 \\
\hline Southeast & 3.80 & 3.82 & 0.88 & 0.42 & 0.72 & 0.73 & 0.96 & 1.10 & 1.28 & 0.86 & 1.40 & 1.86 \\
\hline South-west & 0.00 & 0.00 & 1.53 & 1.00 & 2.45 & 2.78 & 1.09 & 0.81 & 0.00 & 0.00 & 0.15 & 0.00 \\
\hline
\end{tabular}

Source: The Authors, 2021

Fonte: Os autores, 2021.

The LQ's: Seeds/Southeast (2005 and 2015): 3.80 and 3.82; Seedlings/Northwest (2005 and 2015): 5.52 and 4.30; Firewood/Oeste (2005): 6.53 and Firewood/ Northwest (2015): 4.83; Sawmill and Lamination/South Center (2005): 1.11 and Sawmill and Lamination/Metropolitan Region of Curitiba (2015): 1.28; Cellulose and

FLORESTA, Curitiba, PR, v. 51, n. 2, p. 400-409, abril/jun 2021. 
Paper/Central-Eastern (2005 and 2015): 1.98 and 3.55; Other products/Pioneer North (2005): 6.96 and Other products/South-Center(2015): 3.17 demonstrate the highest values obtained for each product analyzed for 2005 and 2015. In a ten-year interval only for seeds, seedlings, cellulose, and paper, LQ remained from little specialized to highly specialized.

Table 2. Gross Value of production by product - 2005 and 2015 ( $\$$ millions)

Tabela 2. Valor Bruto da Produção por produto - 2005 e 2015 (R\$ milhões)

\begin{tabular}{|c|c|c|c|c|c|c|c|c|c|c|c|c|}
\hline \multirow{3}{*}{ Mesoregion } & \multicolumn{2}{|c|}{ Seeds } & \multicolumn{2}{|c|}{ Seedlings } & \multicolumn{2}{|c|}{ Firewood } & \multicolumn{2}{|c|}{$\begin{array}{l}\text { Sawmill and } \\
\text { Lamination }\end{array}$} & \multicolumn{2}{|c|}{$\begin{array}{c}\text { Cellulose and } \\
\text { paper }\end{array}$} & \multicolumn{2}{|c|}{$\begin{array}{c}\text { Other } \\
\text { Products }\end{array}$} \\
\hline & \multicolumn{2}{|c|}{ Year } & \multicolumn{2}{|c|}{ Year } & \multicolumn{2}{|c|}{ Year } & \multicolumn{2}{|c|}{ Year } & \multicolumn{2}{|c|}{ Year } & \multicolumn{2}{|c|}{ Year } \\
\hline & 2005 & 2015 & 2005 & 2015 & 2005 & 2015 & 2005 & 2015 & 2005 & 2015 & 2005 & 2015 \\
\hline Midwest & & & 0.62 & 1.12 & 2.62 & 21.02 & 26.09 & 26.36 & 0.20 & & 0.35 & 0.05 \\
\hline Central-Eastern & & & 2.61 & 14.57 & 9.64 & 66.09 & 517.68 & 161.60 & 140.29 & 314.01 & 0.80 & \\
\hline South-Center & 0.00 & & 6.49 & 4.29 & 11.59 & 62.18 & 459.65 & 355.40 & 7.00 & 25.82 & 23.95 & 24.16 \\
\hline $\begin{array}{l}\text { Metropolitan } \\
\text { Region of } \\
\text { Curitiba }\end{array}$ & & & 1.29 & 4.58 & 18.67 & 43.47 & 603.83 & 518.52 & 55.24 & 60.79 & 1.35 & \\
\hline Northwest & & & 1.78 & 1.97 & 7.45 & 30.52 & 31.23 & 5.30 & & & 1.16 & \\
\hline Pioneer North & & & 0.63 & 1.18 & 14.45 & 80.20 & 73.03 & 243.68 & 13.85 & 6.85 & 27.97 & \\
\hline North-Central & & & 0.95 & 2.57 & 3.73 & 27.13 & 35.49 & 96.01 & 1.59 & 3.14 & 2.33 & 0.79 \\
\hline West & & & 2.80 & 4.42 & 18.90 & 74.21 & 50.26 & 73.62 & 0.02 & & 2.44 & 2.52 \\
\hline Southeast & 0.10 & 0.05 & 5.56 & 4.40 & 22.95 & 106.08 & 645.10 & 615.40 & 110.89 & 118.53 & 35.63 & 26.13 \\
\hline South-west & & & 1.41 & 1.18 & 11.30 & 45.11 & 105.56 & 50.72 & 0.02 & & 0.55 & \\
\hline
\end{tabular}

Source: SEAB (2021).

Fonte: SEAB (2021).

The Table 2 shows the GVP's of the mesoregions of Paraná in millions of reais. These values refer to all cultivated products that form the Gross Value of Production and therefore, there may be differences when compared directly with the Locational Quotient. That is, the GVP considers the values of all products while the LQ used considers only the production value of the selected products. In addition, the LQ equation is formed by two fractions, with variable numerators and denominators always fixed; thus, small changes in the GVP of product " $i$ " in mesoregion " $j$ " and in the GVP of all analyzed products in mesoregion " $j$ " can result in large variations in LQ due to the existence of two fixed terms.

\section{Seeds}

For the seed product, several were the mesoregions with LQ equal to zero. This is due to the low level of production. In the Southeast region in 2005, five cities predominated: Bituruna, Cruz Machado, Paula Freitas, Paulo Frontin and União da Vitória, with Cruz Machado being the region with the highest level of production (R\$ 96,250). It is worth noting that in the Central-South mesoregion there was also production, albeit small. In 2015, only two cities had production: Bituruna and Cruz Machado, which again confirms a LQ equal to zero for the other regions studied. About the Gross Value of the Product, there was a decrease from R $\$ 0.10$ million (2005) to R\$ 0.05 million (2015); however, this fall did not affect the LQ, which showed slight growth, as it went from 3.80 in 2005 to 3.82 in 2015 . This is due to the dynamics of variation between the total (all the products of a GVP) and the total of the seed product that were compensated for each other.

\section{Seedlings}

Seedling cultivation is highly dispersed in the state of Paraná, which results in production in all mesoregions. It is worth mentioning the production of some of these cities in 2005: Marmeleiro (South-west) with 800 thousand units of seedlings of exotic forest essences; Foz do Iguaçu (West) with 365 thousand units of seedlings of native forest essences; Cianorte (Northwest) with more than 3 million units of Eucalyptus seedlings; Iporã (Northwest) with 100 thousand units of Grevilea; Guarapuava (Center-South) with 92 thousand units of Pinheiro seedlings and; Palmas (Center-South) with more than 15 million units of pine seedlings.

In 2015, we can highlight: Cianorte (Northwest) with 120 thousand units of exotic forest essences seedlings; Apucarana (North-Central) with more than 2 million units of seedlings of native forest essences; Sengés (Central-Eastern) with more than 6 million units of Eucalyptus seedlings; and Telêmaco Borba (Central-Eastern)

FLORESTA, Curitiba, PR, v. 51, n. 2, p. 400-409, abril/jun 2021. 
with more than 14 million units of Pinus seedlings. For the other species, there was no record by SEAB in 2015, so there are no statistics presented.

Nine mesoregions had a reduction in their LQ, with the exception only of the metropolitan region of Curitiba since it went from 0.24 to 0.60 . Despite the elevation, the region has a low concentration of seedlings. It is worth mentioning the central-eastern region, which achieved an increase in LQ $(0.50-2.16)$ between 20052015. However, the mesoregion with the highest LQ was the Northwest, whose quotient had a relative drop in specialization, from 5.52 in 2005 to 4.30 in 2015.

In relation to the GVP, other regions stand out, such as the central-south and south-east mesoregion in 2005, while in 2015 there is an emphasis on the central-east with the highest GVP of R\$14.57 million. This increase was higher than the fall in the total GVP of the selected products in the mesoregion, contributing to the increase in the LQ from 0.50 (2005) to 2.16 (2015).

\section{Firewood}

According to Lenha no Brasil (2021), until the beginning of the 2000s firewood was the most used and oldest energy source by the human being, being extremely important in the Brazilian Energy Matrix. The consumption of firewood can be divided into three types: 1) commercial; 2) residential; and 3) industrial: cellulose and paper, food and beverages, ceramics, charcoal, and others. The industrial sector consumed approximately $23 \%$ of firewood, mainly in the cellulose, paper, food, and beverage industries. However, the residential sector was in greater demand with approximately $29 \%$.

For firewood, it appears that there are six representative regions through the calculated LQ's: centralwestern, northwest, north-pioneer, north-central, west, and southwest. In 2005 the highlighted region was to the West $(\mathrm{LQ}=6.53)$ and in 2015 it became to the Northwest, since its $\mathrm{LQ}$ in 2005 was 4.60 and increased to 4.83, which means that the region is highly specialized in firewood. Therefore, the Northwest in 2015 participated more intensively in the formation of the GVP. There are 61 cities that participate in the formation of the firewood GVP, which demonstrates the decentralization of the activity.

For LQ the main mesoregions are: West and Northwest, while for GVP are (2005): the Metropolitan Region of Curitiba, West and Southeast; for 2015, we have: Central-West, Eastern Center, Pioneer North and Southeast. It is evident how much the variation of the other analyzed products interferes in the LQ result for a specific product.

\section{Sawmill and Lamination}

The results obtained with the Locational Quotients demonstrated that there are 5 locations with a small positive variation and another 5 locations with negative variation. Sawmill and laminating wood have low specialization in all studied mesoregions. However, it can be emphasized that the northwest mesoregion had a great reduction in its participation, going from a $\mathrm{LQ}=0.92$ to $\mathrm{LQ}=0.22$. The three mesoregions with the highest participation are: central-western (Moreira Sales: 78,000 $\mathrm{m}^{3} /$ Eucalyptus in 2005; Peabiru with 50,000 $\mathrm{m}^{3} /$ Eucalyptus in 2015), west (Cascavel: $80,000 \mathrm{~m}^{3} /$ Pinus (2005) - Cascavel: $196,000 \mathrm{~m}^{3} /$ Pinus in 2015) and southwest (Renascença: 95,440 m³ Pinus in 2005 - Francisco Beltrão with 75,000 $\mathrm{m}^{3} /$ Pinus in 2015). Possibly, due to low specialization, some regions have expended strength for other crops.

In the Gross Value of Production, there was also a decrease in most of the mesoregions. Both positive and negative fluctuations in the GVP's are not matched in the LQ's shown. For the Central-Eastern GVP increased in the period ( $\mathrm{R} \$ 26.09-\mathrm{R} \$ 26.36$ million), while the LQ decreased $(1.07-0.84)$. Demonstrating that they are differentiated forms of assessment, not being subject to a corresponding assessment.

\section{Cellulose and paper}

In 2005, roundwood for cellulose had some share value in all mesoregions even with little representation. In 2015, six mesoregions contributed to the formation of the GVP: eastern center, central-south, metropolitan region of Curitiba, Pioneer North, North-Central and Southeast. Except for the central-eastern region, the other regions have weak or unrepresentative specialization. The Eastern Center (2015) is characterized as specialized, with 4 cities the main responsible for the specialization: Ortigueira (14.04\%), Reserva (14.6\%), Telêmaco Borba (30.15\%) and Tibagi (15.42\%).

Both the Locational Quotient and the Gross Value of Production were highly representative in the CentralEastern region. For the first, it obtained: 1.98 (2005) and 3.55 (2015) and for the GVP: R\$ 140.29 million in 2005 and $\mathrm{R} \$ 314.01$ million. It is worth mentioning that in this mesoregion it has Klabin units, being a strong company representing cellulose and paper. 


\section{Other products}

The sub-item "Other products" refers to pine knot, poplar, fence posts, wood splinters and forest residues. In 2005, there were two mesoregions with representativeness: North Pioneer $(L Q=6.96)$, being specialized and North-Central (LQ = 1.70), being little specialized. In 2015 the dynamic center changes and the highlight is for the center south $(\mathrm{LQ}=3.17)$ and the Southeast $(\mathrm{LQ}=1.86)$. The calculation of the $\mathrm{LQ}$ for the other products captured the largest variations in the whole, since the available data are aggregated.

However, variations in demand and supply for other products may vary both directly and indirectly in the Location Coefficients. The municipalities that captured the greatest variations were (2015): Coronel Domingos Soares with $12.47 \%$ of forest residues and Palmas with $8.4 \%$. The calculated LQ has generally followed the GVP's dynamics, however in 2015 several mesoregions did not participate in the construction of the GVP or at least did not present statistical data to be accounted for.

\section{DISCUSSION}

\section{Seeds}

In Table 2 there was a big drop in the GVP of seeds between 2005 - 2015 but that the LQ's presented had values close to: 3.80 (2005) and 3.82 (2015). Despite the drop in GVP between the periods (2005: R $\$ 0.10$ million -2015: R\$ 0.05 million) there was compensation in the total variation of all selected products from all mesoregions between the periods analyzed, which resulted in similar LQ's.

Regarding the analysis material, in the database used there are only Pinus and Bracatinga, with Pinus seeds coming from the central-south mesoregion and Bracatinga seeds from the southeast mesoregion. In 2005, five regions were responsible for the GVP, with the largest share being 5.25\% for Bituruna and 91.79\% for Cruz Machado. In 2015, the Southeast ended up being the only mesoregion to participate in the formation of the GVP with $25 \%$ represented by Bituruna and $75 \%$ coming from Cruz Machado specifically with Bracatinga seed.

Therefore, in the state of Paraná, seed production is concentrated in the southeast mesoregion with only Bracatinga seed in 2015. This concentration may be the result of the lack of demand and favorable conditions that do not allow other locations to obtain incentives for seed production/marketing. A corroborating factor for this is the GVP's own downturn.

\section{Seedlings}

In Paraná, the concentration of seedlings, considering the GVP, is in the northwest mesoregion with 23 participating municipalities. However, only 2 stand out: Umuarama responsible for $28.47 \%$ (Eucalyptus seedlings) and Iporã with $42.7 \%$ (Eucalyptus seedlings). Although the seedlings represent the subsequent stage of the seeds, the cultivation of the two is concentrated in vastly different regions, since the first in the southeast and the last in the Northwest. Therefore, the cultivation of seedlings is very dependent on the adequate infrastructure that forest companies can use under suitable conditions. Consequently, the increase in demand for one does not necessarily mean the increase in the other.

It is worth mentioning that the mesoregions that have the highest LQ's did not always obtain the highest GVP. For example, Seedlings is highly specialized in the northwest mesoregion considering the calculated LQ's, however, the highest GVP was in 2005 in the central-south mesoregion (R\$ 6.49 million) and in 2015 in the centraleastern mesoregion (R 14.57 million), which shows a difference in benefit between regions. Thus, the Locational Quotients obtained are extremely sensitive to the current values of the product in its mesoregion, as well as its weight given the sum of all mesoregions of that product. Therefore, it is clear the importance of making an analysis of the whole and not only of the individual.

\section{Firewood}

The city with the predominance of activity in both 2005 and 2015 was Telêmaco Borba, since the value of production in 2005 was $\mathrm{R} \$ 4,576,698$; and in 2015 it was $\mathrm{R} \$ 34,905,786$, which reflected a significant increase in LQ for the Central-Eastern mesoregion, from 0.37 to 0.71 . As there are several municipalities participating in the activity, the fact that Telêmaco Borba has a higher production value does not make the Central-Eastern region with higher LQ than other regions; because it is gained through the volume of participating cities, resulting in a higher production value per mesoregion and consequently in its LQ. As for the small positive variations in some mesoregions, it is expected that there may be seasonal variations in demand that justify a small positive variation in the LQ's presented.

When the GVP is verified, it is noticed that all mesoregions have significant importance in the commercialization of firewood, since all had an increase in GVP. However, when comparing the downward variations (2005-2015) of the LQ's of the following mesoregions: pioneer north (2.86-1.45), central north (2.18-

FLORESTA, Curitiba, PR, v. 51, n. 2, p. 400-409, abril/jun 2021. 
1.25 ) and west (6.53-2.87); it can be inferred that the reduction in the demand for activities would negatively impact the demand for firewood, that is, the result of the fall in demand for wood for firewood during the selected period. However, the various negative oscillations presented in the LQ's are the result of the increase in GVP's along with the use of the fixed denominator of the equations, which contributes to greater or lesser power of characterization in the calculated LQ's. In this way, some LQ's can faithfully represent the specialization of the activity or not.

\section{Sawmill and Lamination}

According to SEAB (2015), in the period from 2005 to 2015 the sawmill and rolling mill activity fluctuated in its production and consequently in its Gross Value of Production. This shows that it was not just a one-off drop between 2005 and 2015, but that there was a drop in demand by the manufacturing industry, civil construction, furniture, and other activities during the period. Of the 10 mesoregions analyzed, 5 had a decrease in LQ: Central-West, Central-Eastern, Northwest, West and Southwest; and 6 mesoregions with a drop in GVP: Central-Eastern, Central-South, Metropolitan Region of Curitiba, Northwest, Southeast and Southwest.

For LQ to accurately capture variations in GVP's considering the totals used as fixed terms, there must be an abrupt variation between 2005 and 2015. For example, Northwest had GVP $2005=\mathrm{R} \$ 31.23$ million and GVP $2015=\mathrm{R} \$ 5.30$ million and LQ $2005=0.92$ and LQ $2015=0.22$. The Pioneer North had GVP $2005=\mathrm{R} \$$ 73.03 million and GVP 2015 = R \$243.68 million, the LQ's were 2005: 0.69 and 2015: 1.14. The positive/negative variations in GVP's accompanied by positive/negative variations in the LQ's were possible because in addition to the abrupt variations in the GVP of the product itself, the terms in the total GVP accompanied the oscillation of the period.

\section{Cellulose and paper}

In addition, according to statistical data from IPARDES (2021) the physical production of the manufacturing industry in Paraná, specifically for wood, cellulose, and paper products, presented a downward trend from September 2016. Therefore, the construction industry, furniture, activities that demand newspapers, magazines, records, packaging, among others, had a drop in demand, generating a cyclical effect.

It is also understood that although the production chain follows the tendency to fall or grow, variations can occur in specific areas that are not noticeable in the aggregate. However, for Cellulose and Paper, most of the calculated LQ's had a corresponding variation with the GVP's due to the large difference in value between the periods and significant variation in the mesoregion totals.

\section{Other products}

This category, for presenting several products, is not accurately able to show the GVP concentration of each product. In the year 2005, wood for pine knots, fence posts and splinters were considered in the SEAB database, while in 2015 wood was considered for: poplar, pine knots and forest residues. Thus, the dynamics for each product is not captured individually, but only in the aggregate.

\section{CONCLUSIONS}

- Considering that the study is specific to the state of Paraná and that the database made available by SEAB, regarding seeds, considers only the cultivation of Bracatinga and Pinus seeds, the predominant mesoregion is the Southeast. Therefore, there was only significant LQ for this region, in addition to several nurseries of forest species (seedlings and seeds) in cities in the Southeast such as Cruz Machado and Bituruna. Therefore, specialization in seed culture in both 2005 and 2015 is the result of the consolidation of the necessary conditions and the demand for this type of seed. In addition, the LQ formula itself corroborated for the permanence of significant LQ's;

- All analyzed mesoregions participated in the cultivation of seedlings and wood for firewood, which shows the decentralized condition of these products, with emphasis on the West and Northwest. The northwestern mesoregion was specialized and highly specialized in the study. Therefore, the largest LQ's presented are the result of the diversity of products grown in the various cities involved in this mesoregion. However, the LQ's presented are not always able to faithfully capture the variations of the GVP's given the structure of the LQ;

- The LQ's for sawmill and rolling mills demonstrated that there is little specialization in this activity, since it is much decentralized. The small positive variations, in addition to the negative variations, result from the drop in demand for various activities that are dependent on this first one, which results in a low or little specialized LQ. However, it is an activity of great importance, when verified from the perspective of the GVP, since the variations of the GVP's are also not faithfully captured by the Locational Quotient;

FLORESTA, Curitiba, PR, v. 51, n. 2, p. 400-409, abril/jun 2021. 
- The cellulose and paper business were very prominent in the Central-Eastern mesoregion, with an increase in LQ. This increase is indicative of the increase in activity, which has several industries in the region. As a result of this concentration, LQ's would be superior to other mesoregions that do not have industries;

- The Other Products, which consists of a group of products with LQ in 2005 highly specialized for the North Pioneer and in 2015 specialized for the Center-South, presents the fall in the production of "splinters" in the North-Pioneer and the rise of forest residues strongly in cities in the central-south mesoregion;

- However, it is still important to analyze other indicators that can support the better understanding of each mesoregion and thus contribute to its development.

\section{ACKNOWLEDGEMENTS}

The authors would like to thank the Coordination for the Improvement of Higher Education Personnel for the availability of a doctoral research scholarship for the participating student.

\section{REFERENCES}

AZEVEDO JUNIOR, W. C. de; DALlEMOLE, D.; FARIA, A. M. de M. Análise locacional e impactos econômicos do segmento sucroalcooleiro em Mato Grosso. Revista Estudos CEPE, no 35, jan./jun. de 2012, p. 259-285.

CENED. A floresta e sua importância. Available in: <https://www.cenedcursos.com.br/meio-ambiente/afloresta-e-sua-importancia/>. Accessed on: January 30, 2021.

DELGADO; A. P.; GODINHO, I. M. (2011). Capítulo 1: medidas de localização das atividades e de especialização regional. In: COSTA, J. S.; DENTINHO, T. P.; NIJKAMP, P. (Coords.) (2011). Compêndio de economia regional - volume II: métodos e técnicas de análise regional. Parede: Principia, 2011.

HOEFlich, V. A.; SIlva, A. J.; SANTOS, A. J. Política Florestal: Conceitos e Princípios para a sua formulação e implementação. Embrapa Florestas. Colombo- $P R, 2007$.

IBGE. Paraná. Available in: <https://cidades.ibge.gov.br/brasil/pr/panorama>. Accessed on: January 30, 2021.

IPARDES. Paraná - síntese de indicadores. Available in: $<$ http://www.ipardes.pr.gov.br/index.php?pg_conteudo=1\&sistemas $=1 \&$ cod_sistema $=5 \&$ grupo_indic $=4>$. Accessed on: January 30, 2021.

FAO. Non-wood forest products for rural income and sustainable forestry. Available in: <http://www.fao.org/docrep/V9480E/v9480e04.htm\#why\%20are\%20non\%20wood\%20forest\%20products\%20i mportant $>$. Accessed on: January 30, 2021.

LENHA NO BRASIL. Lenha. Available in: <http://infoener.iee.usp.br/scripts/biomassa/br_lenha.asp>. Accessed on: January 30, 2021.

MARION FILHO, P. J.; MOURA, A. C.; BRITES, M.; LORENZONI, R. K. Concentração regional e especialização na produção de leite do Rio Grande do Sul (1990 - 2010). Revista Brasileira de Gestão e Desenvolvimento Regional, [Taubaté], v.11, n. 1,jan-abr/2015.

Available in: < file://C:/Documents\%20and\%20Settings/Keila/Meus\%20documentos/Downloads/1419-6244-1PB.pdf $>$. Accessed on: January 31, 2021.

MATTEI, T. F.; MATTEI, T. S. Métodos de análise regional: um estudo de localização e especialização para a região sul do Brasil. Revista Paranaense de Desenvolvimento, vol. 38, nº 133, jul./dez. de 2017, p. 227-243.

MOREIRA, J. M. M. A. P.; OLIVEIRA, E. B. de. Capítulo 1: Importância do setor florestal brasileiro com ênfase nas plantações florestais comerciais. In: OLIVEIRA, Y. M. M. de; OLIVEIRA, E. B. de (Ed.). Plantações florestais: geração de benefícios com baixo impacto ambiental. Brasília, DF: Embrapa, 2017, p. 11-20.

PIFFER, M.; AREND, S. C. A agropecuária e as indústrias tradicionais no desenvolvimento regional paranaense no período de 1970 a 2000. Informe Gepec, vol. 13, nº 1, jan./jun. de 2009, p. 107-122.

FLORESTA, Curitiba, PR, v. 51, n. 2, p. 400-409, abril/jun 2021.

Bittencourt, K. C. et.al.

ISSN eletrônico 1982-4688 
ROCHA, J. Dores de Sá; SILVA, J. A. As Funções de Estado na área florestal: suas inter-relações com a Constituição Federal e com o programa nacional de florestas. FLORESTA, Curitiba, PR, v. 39, n. 2, p. 253271, abr./jun. 2009.

SCIELO, Coeficientes de Gini locacionais - GL: aplicação à indústria de calçados do Estado de São Paulo. Available

in:

$<$ http://webcache.googleusercontent.com/search?q=cache:CJnSOO7Y8D4J:wwwp.feb.unesp.br/renofio/produca o\%2520limpa/Van/Couro/SuziganCoeficientGiniLocais.pdf $+\& \mathrm{~cd}=3 \& \mathrm{hl}=\mathrm{pt}-\mathrm{BR} \& \mathrm{ct}=\mathrm{clnk} \& \mathrm{gl}=\mathrm{br}>$. Accessed on: January 26, 2021.

SCIELO, Dinâmica de Ocupação do Cerrado Nordestino pela Agricultura: 1990 e 2012. Available in: $<$ http://www.scielo.br/scielo.php?script=sci_arttext\&pid=S0103-20032016000200319>. Accessed on: January $28,2021$.

SCIELO, Políticas públicas e manejo comunitário de recursos naturais na Amazônia. Available in: $<$ http://www.scielo.br/scielo.php?pid=S1414-753X2003000300009\&script=sci_arttext $>$. Accessed on: January $30,2021$.

SEAB, Secretaria de Estado de Agricultura e Abastecimento. Valor Bruto da Produção Agropecuária. Available in: <http://www.agricultura.pr.gov.br/arquivos/File/deral/VBP_2015_AnaliseCompletaVD1.pdf >. Accessed on: January 20, 2021.

SEAB, Secretaria de Estado de Agricultura e Abastecimento. Valor Bruto da Produção Agropecuária. Available in: <http://www.agricultura.pr.gov.br/arquivos/File/deral/AnaliseVBP2017ResumidaVD.pdf >. Accessed on: January 3, 2021.

SOUZA, E. C. de; GOMES, M. F. M.; LÍRIO, V. S. Análise locacional da produção vegetal nas Mesorregiões Geográficas Paranaenses. Redes, [Santa Cruz do Sul], v. 12, n. 3, set/dez/2007. Available in: <file://C:/Documents\%20and\%20Settings/Keila/Meus\%20documentos/Downloads/432-1319-2-

PB\%20(1).pdf>. Accessed on: January 31, 2021.

SERVIÇO FLORESTAL BRASILEIRO - SFB. Sistema Nacional de Informações Florestais - SNIF. Available in: 〈http://snif.florestal.gov.br/pt-br/estatisticas-florestais〉. Accessed on: January 15, 2021.

FLORESTA, Curitiba, PR, v. 51, n. 2, p. 400-409, abril/jun 2021 